\title{
PENENTUAN GRADING TUMOR GANAS ORAL SQUAMOUS CELL CARCINOMA BERDASARKAN GAMBARAN HISTOPATOLOGI
}

\author{
(DETERMINATION OF GRADING MALIGNANT TUMOR ORAL \\ SQUAMOUS CELL CARCINOMA BASED ON HISTOPATOLOGICAL \\ VIEW)
}

\author{
Theresia Indah Bhudy ${ }^{1}$ Bambang Soemaryono $^{2}$ Urfa Aprillia $^{3}$ \\ Departemen Patologi Mulut dan Maksilofasial \\ Fakultas Kedokteran Gigi Universitas Airlangga \\ Suabaya - Indonesia \\ E-mail: urfaaaprillia@gmail.com.
}

\begin{abstract}
Background: Approximately 95\% of malignant tumors are histologically classified as Oral Squamous Cell Carcinoma (OSCC). Microscopically OSCC is classified based on methods that take into account subjective assessments, rates of keratinization, pleomorphic nucleus and cellular, and mitotic activity. These levels include well differentiated (grade III), moderately differentiated (grade III), and poorly differentiated (grade IV). Well and moderately differentiated can be classified as low grade while poorly differentiated tumor as high grade. The best standards for diagnosing OSCC are histopathological examination and tissue biopsy of the lesion. Purpose: This study aims to determine the grading of OSCC malignant tumors based on histopathologic features Methods: The sample consisted of 6 types of OSCC then performed preparation of malignant OSCC tumor tissue into paraffin block and stained using hematoxyin eosin (HE). The histopathological features of the six samples were observed under a light microscope with 100x and 400x magnification. Result: From 6 cases, one of them is diagnosed as well differentiated (stage I), two cases are welldifferentiated (stage II), two cases were diagnosed moderately differentiated (stage III), and poorly differentiated (stage IV).Conclusion: The OSCC is classified by histopathology into well differentiated (stage I-II), moderately differentiated (stage III), and poorly differentiated (stage IV)
\end{abstract}

Key words: OSCC, well differentiated, moderately differentiated, poorly differentiated

Latar Belakang: Sekitar 95\% dari tumor ganas diklasifikassikan secara histologis sebagai Oral Squamous Cell Carcinoma (OSCC). Secara mikroskopis OSCC diklasifikasikan berdasarkan pada metode yang mempehitungkan penilaian subjektif, tingkat keratinisasi, pleomorfik nukleus dan seluler, dan aktivitas mitosis. Tingkatan tersebut meliputi well differentiated (grade I-II), moderately differentiated (grade III), dan poorly differentiated (grade IV). Well dan moderately differentiated dapat dikelompokkan sebagai low grade sedangkan poorly differentiated tumor sebagai high grade. Standar yang paling baik untuk menegakkan diagnosis OSCC adalah pemeriksaan histopatologis dan biopsi jaringan lesi tersebut. Tujuan: Penelitian ini bertujuan untuk menentukan grading tumor ganas OSCC berdasarkan gambaran histopatologi. Metode: Sampel terdiri dari 6 jenis OSCC kemudian dilakukan pembuatan sediaan jaringan tumor ganas OSCC kedalam blok paraffin dan dilakukan pengecatan menggunakan hematoxilin eosin (HE). Gambaran histopatologi dari keenam sampel diamati dibawah mikroskop cahaya dengan pembesaran 100x dan 400x. Hasil: Dari 6 kasus yang ditemukan satu terdiagnosa sebagai well differentiated (stage I), dua kasus terdiagnosa well differentiated(sstage II), dua kasus terdiagnosa moderately differentiated (stage III), dan poorly differentiated (stage $I V$ ). Kesimpulan: OSCC diklasifikasikan berdasarkan gambaran histopatologi kedalam well differentiated (stage I-II), moderately differentiated (stage III), dan poorly differentiated (stage IV)

Kata Kunci : OSCC, well differentiated, moderately differentiated, poorly differentiated 


\section{PENDAHULUAN}

Neoplasma adalah kumpulan massa abnormal yang terbentuk oleh sel yang tumbuh terus menerus secara tidak terbatas, tidak berkoordinasi dengan jaringan di sekitarnya dan tidak berguna bagi tubuh. Neoplasma disebut juga tumor. ${ }^{1}$ Neoplasma di rongga mulut dapat bersifat jinak, praganas, ataupun ganas yang dapat berasal dari sel odontogen atau non-odontogen. Berasarkan sifatnya, terdapat dua tipe neoplasma, yakni neoplasma jinak (benign neoplasm) dan neoplasia ganas (malignant neoplasm). Neoplasia ganas adalah tumor yang tumbuhnya cepat, infiltratif ke jaringan sekitarnya, dan dapat menyebar ke organorgan lainnya (metastasis). ${ }^{2}$

Pertumbuhan neeoplasma dapat dinamakan dan diklasifikasikan berdasarkan beberapa sistem. Sebagian besar tumor - tumor diklasifikasikan berdasarkan asal jaringan. Semua neoplasma jinak diberi akhiran -oma. Neoplasia ganas yang berasal dari jaringan epitel disebut karsinoma, sedangkan yang berasal dari jaringan mesenkimal disebut dengan sarcoma. ${ }^{3}$

Oral Cancer (OC)/Kanker mulut menduduki peringkat 6 sampai 8 dari seluruh jenis kanker yang paling sering terjadi di seluruh dunia, dengan angka kejadian 300.000 setiap tahunnya. ${ }^{4}$ Sekitar $95 \%$ dari kasus kanker mulut diklasifikasikan secara histologis sebagai oral squamous cell carcinoma (OSCC), sisanya 5\% termasuk varian histologis seperti oral verrucous carcinoma, adeno squamous carcinoma, adenoid squamous cell carcinoma, mucoepidermoid carcinoma, dan basaloid squamous cell carcinoma. ${ }^{5}$ Oral squamous cell carcinoma adalah neoplasma maligna yang berasal dari keratinosit superbasal epidermis. Neoplasma ini merupakan jenis neoplasma non melanoma terbanyak kedua setelah karsinoma sel basal. ${ }^{6}$

Manajemen yang tepat untuk pasien dengan lesi mulut ganas atau pra ganas dimulai dengan diagnosis yang akurat. Standar yang paling baik saat ini untuk menegakkan diagnosis adalah pemeriksaan histopatologis dari biopsi jaringan lesi yang dicurigai. Diagnosis histopatologis yang akurat bergantung pada klinisi/dokter yang melakukan biopsi dengan tepat dan dapat memberikan informasi klinis yang memadai, dan juga bergantung pada ahli patologi yang dapat menafsirkan dengan benar hasil dari biopsi. ${ }^{7}$

\section{BAHAN DAN METODE}

Penelitian ini merupakan penelitian deskriptif dengan jumlah sampel sebanyak 6 kasus. Sampel penelitian diambil dari data sekunder penderita oral squamous cell carcinoma yang sudah dilakukan pembuatan sediaan histopatologi. Sediaan dicat menggunakan pengecatn Hematoxilin Eosin (HE). Kemudian Masingmasing sampel dilakukan pengamatan dibawah mikroskop cahaya dengan pembesaran 100x dan 400x. Variabel penelitian yang diamati adalah prosentase sel atipik, jumlah sel mitosiss, keratin pearl, dan angiogenesis.

\section{HASIL}

Hasil penelitian menunjukkan adanya gambaran keratin pearl pada beeberapa sampel yang teridagnosa sebagau well differentiated (stage I-II) sedangkan pada mioderately differentiated dan poorly differentiated sudah tidak lagi ditemukan adanya keratin pearl. Selain bentukan keratin pearl, gambaran sel atipia, sel mitosis, dan angiogenesis juga tampak pada gambaran histopatologi OSCC.

Pada kasus pertama menunjukkan adanya gambaran keratin pearl, angiogenesis, sel-sel yang mengalami mitosis, dan sel atipik. Pada kasus 1 ditemukan gambaran keratin pearl pada satu lapang pandang, jumlah sel-sel yang mengalami mitosis sebanyak 6 dan prosentase sel atipik sebesar $60 \%$.

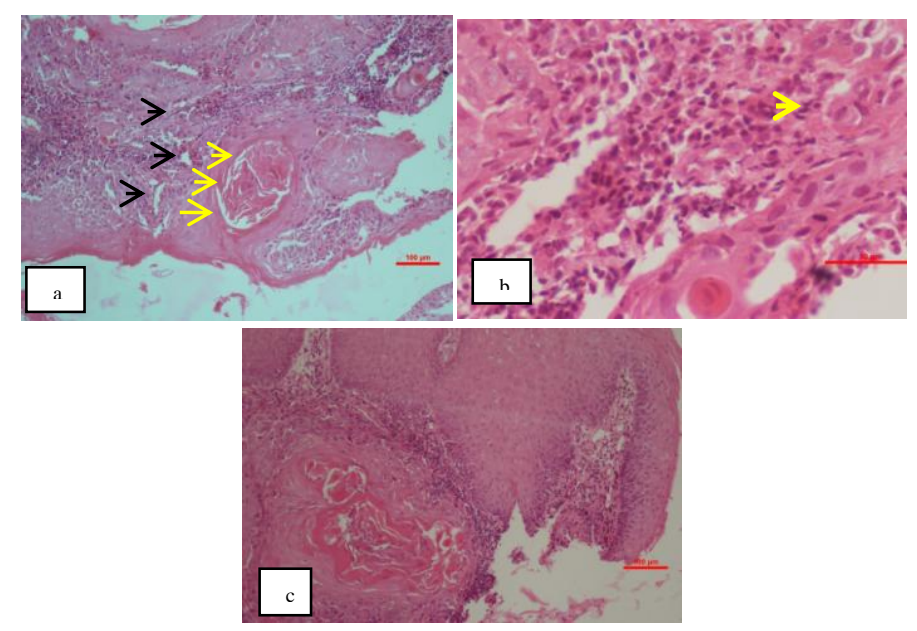

Gambar 1. Gambaran keratin pearl, sel atipik, dan sel mitosis pada sampel pertama. 


\section{Keterangan :}

(a) menunjukkan adanya gambaran keratin pearl $(\rightarrow)$ dan angiogenesis $(\rightarrow$ ) pada satu lapang pandang,pembesaran $10 \mathrm{x}$ (b) menunjukkan gambaran sel yang mengalami mitosis $(\rightarrow)$ dan sel atipik $(\rightarrow)$, pembesaran 40x (c) menunjukkan gambaran prosentase sel atipik sebesar $60 \%$ pada satu lapang pandang, pembesaran 10x.

Gambar 1 menunjukkan adanya gambaran keratin pearl, angiogenesis, sel-sel yang mengalami mitosis, dan sel atipik. Pada kasus 1 ditemukan gambaran keratin pearl pada satu lapang pandang, jumlah sel-sel yang mengalami mitosis sebanyak 6 dan prosentase sel atipik sebesar $60 \%$.

Pada kasus yang kedua ditemukan adanya gambaran angiogenesis, sel-sel yang mengalami mitosis, dan sel atipik. Pada kasus 2 tidak ditemukan gambaran keratin pearl pada lima lapang pandang, jumlah sel-sel yang mengalami mitosis sebanyak 9 sel dan prosentase sel atipik sebesar $90 \%$.

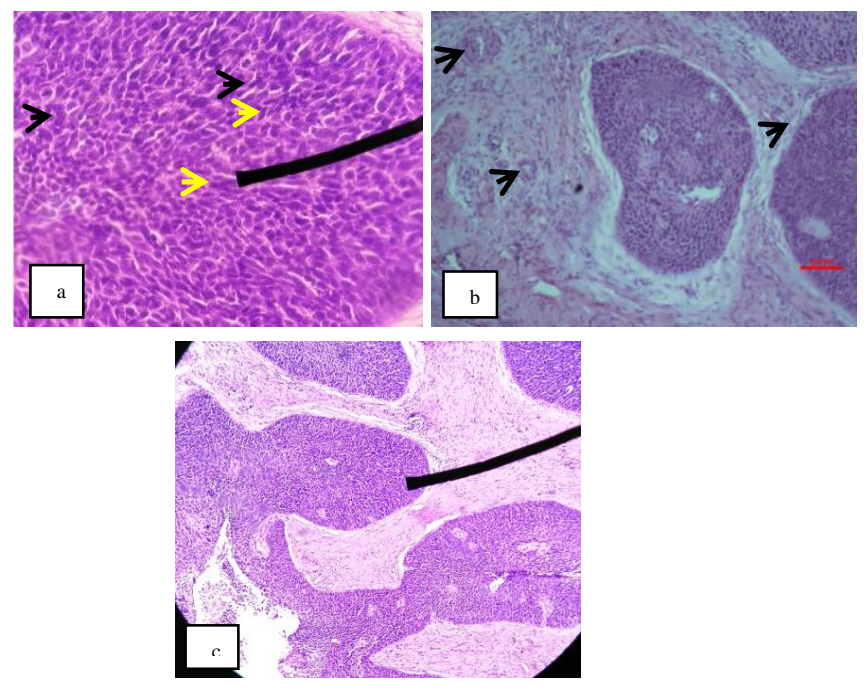

Gambar 2. Gambaran angiogenesis, sel atipik, dan sel mitosis pada sampel kedua.

\section{Keterangan :}

(a) menunjukkan gambaran sel yang mengalami mitosis $(\rightarrow)$ dan sel-sel atipik $(\rightarrow)$, pembesaran 40x (b) menunjukkan gambaran angiogenesis, pembesaran 10x (c) menunjukkan gambaran prosentase sel atipik sebesar $90 \%$, pembesaran 10x

Pada kasus tiga gambaran keratin pearl pada dua lapang pandang dan sel-sel atipik. Pada kasus 3 ditemukan gambaran keratin pearl pada dua lapang pandang, jumlah sel-sel yang mengalami mitosis sebanyak 2 sel dan prosentase sel atipik sebesar $20 \%$.
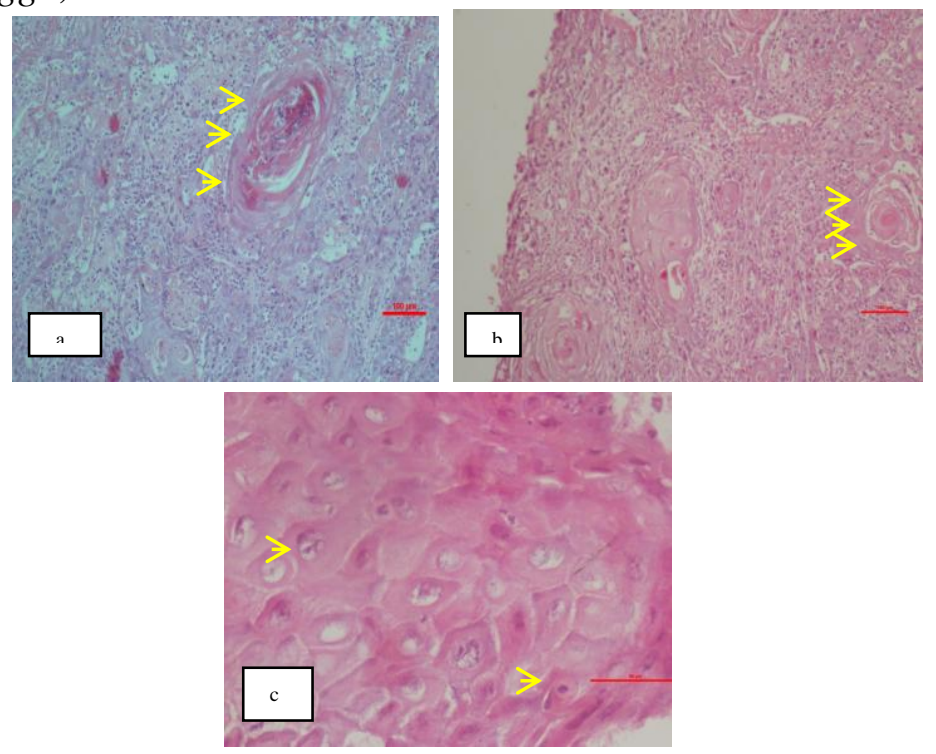

Gambar 3. Gambaran keratin pearl, sel atipik, dan sel mitosis pada sampel ketiga.

Keterangan :

(a) menunjukkan gambaran keratin pearl yang pada lapang pandang 1, pembesaran $10 \mathrm{x}$ (b) menunjukkan gambaran keratin pearl pada lapang pandang 4, pembesaran 10x (c) menunjukkan gambaran sel-sel atipik dengan prosentase $20 \%$, pembesaran $40 x$

Pengamaatan mikroskopis pada kasus keempat menunjukkan adanya gambaran keratin pearl pada satu lapang pandang dan sel-sel atipik. Pada kasus 4 ditemukan gambaran keratin pearl pada lapang pandang 3, jumlah sel-sel yang mengalami mitosis sebanyak 3 dan prosentase sel atipik sebesar $30 \%$.
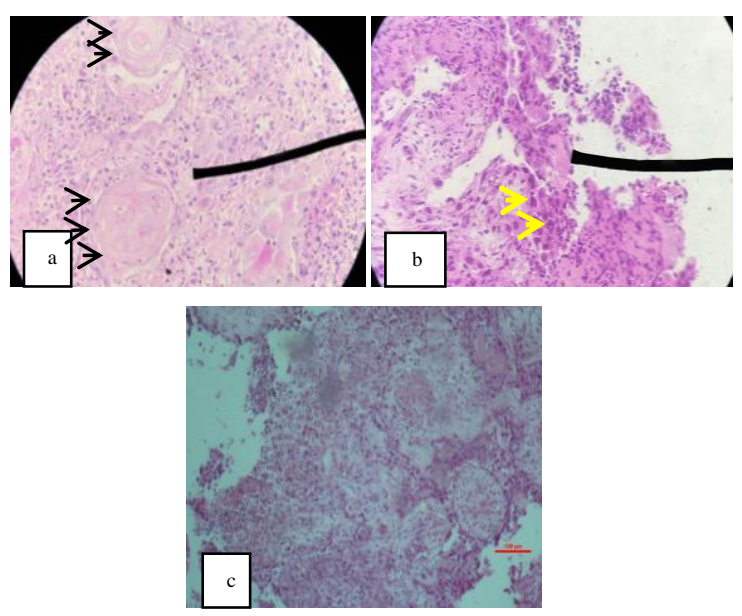

Gambar 4. Gambaran keratin pearl, sel atipik, dan sel mitosis pada sampel keempat. 
Keterangan :

(a) menunjukkan gambaran keratin pearl yang pada lapang pandang 3, pembesaran 40x (b) menunjukkan gambaran sel atipik $(\rightarrow)$ dan sel mitosis $(\rightarrow)$, pembesaran $10 \mathrm{x}$ (c) menunjukkan gambaran sel-sel atipik dengan prosentase $30 \%$, pembesaran $10 \mathrm{x}$

Pada kasus kelima ditemukan adanya gambaran angiogenesis, sel mitosis, dan sel-sel atipik. Tetapi pada kasus 5 tidak ditemukan gambaran keratin pearl pada lima lapang pandang yang diamati, jumlah sel-sel yang mengalami mitosis sebanyak 6 dan prosentase sel atipik

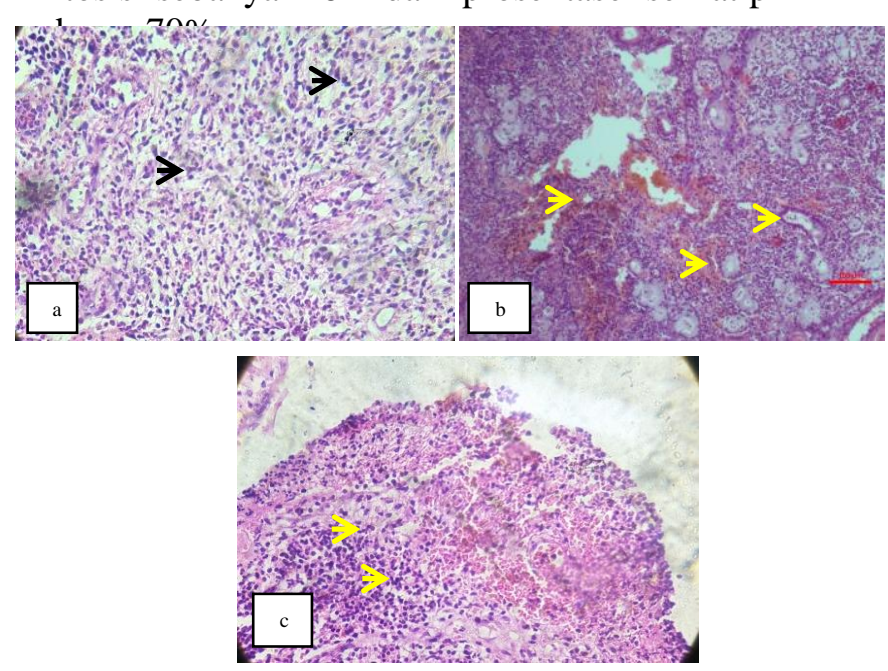

Gambar 5. Gambaran angiogenesis, sel atipik, dan sel mitosis pada sampel kelima.

Keterangan :

(a) menunjukkan gambaran sel mitosis, pembesarn 40x (b) menunjukkan gambaran angiogenesis, pembesaran 10x (c) menunjukkan gambaran sel-sel atipik dengan prosentase $70 \%$, pembesaran $10 \mathrm{x}$

Pada kasus keenam ditemukan adanya gambaran keratin pearl dan sel-sel atipik pada 2 lapang pandang. Pada kasus 6 ditemukan gambaran keratin pearl pada lapang pandang 2 dan 4, jumlah sel-sel yang mengalami mitosis sebanyak 4 dan prosentase sel atipik sebesar $40 \%$
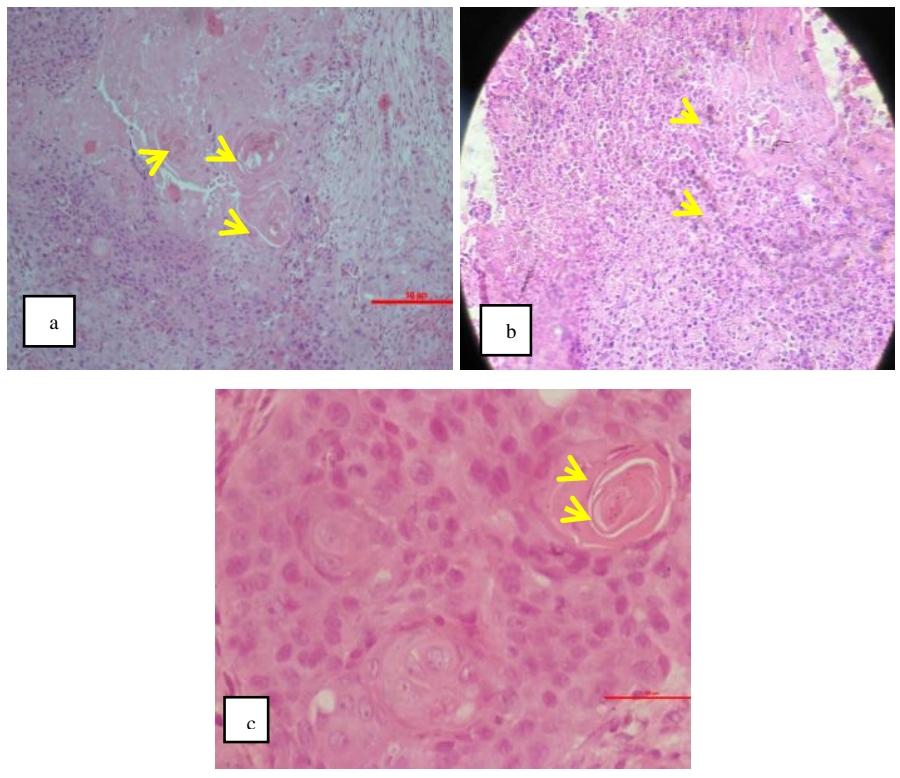

Gambar 6. Gambaran keratin pearl, sel atipik, dan sel mitosis pada sampel keenam.

Keterangan :

(a) menunjukkan gambaran keratin pearl yang letaknya berdekatan yang pada lapang pandang 2 , pembesaran $10 \mathrm{x}$ (b) menunjukkan gambaran sel-sel atipik dengan prossentase $40 \%$, pembesaran 10x (c) menunjukkan gambaran keratin pearl pada lapang pandang 5 , pembesaran $40 \mathrm{x}$

\section{PEMBAHASAN}

Pada penelitian ini, model penelitian menggunakan gross jaringan OSCC. Jaringan tersebut diambil dari pasien OSCC RSUD Dr. Soetomo yang telah melakukan operasi. Dari keenam sampel yang telah didapatkan, tiga sampel terdiagnosa sebagai well differentiated, dua sampel terdiagnosa sebagai moderately differentiated, dan satu sampel terdiagnosa poorly differentiated.

Hasil pengamatan mikroskopis didapatkan prosentase sel atipik pada sampel pertama dan kelima masing-masing sebesar $60 \%$ dan $70 \%$. Hal tersebut menunjukkan angka sel yang tidak mengalami diferensiasi. Menurut klasifikasi Broders sampel tersebut termasuk kedalam stadium III (moderately differentiated) dengan jumlah sel yang tidak terdiferensiasi sebesar 50$75 \% .^{8}$

Pada sampel kedua didapatkan prosentase sel atipik sebesar 90\%. Klasifikasi OSCC secara HPA sesuai dengan stadium-IV kriteria Broders yang menunjukkan jumlah sel yang berdiferensiasi baik kurang dari $25 \%$ serta jumlah sel yang tidak berdiferensiasi lebih dari $75 \%$, tanpa menemukan 
gambaran keratinisasi dan jembatan interseluler.

Keadaan ini juga sesuai dengan klasifikasi

keratin pearl. Hal tersebut diperkuat dengan pendapat Koshy et al tumor dengan gambaran poorlydifferentiated ditandai dengan pleomorfism inti dan sel, tetapi tidak mengandung jembatan interseluler. ${ }^{9}$

Hasil pengamatan mikroskopis pada sampel ketiga, keempat dan keenam dari didapatkan gambaran histopatologi berupa beberapa bentukan keratin pearl yang merupakan sel-sel yang terkeratinisasi secara abnormal, berlapis-lapis dan berupa fokus yang bulat yang dapat diproduksi di dalam epitel lesi. Sehingga sampel-sampel ini terdiagnosa sebagai well differentiated (grade I). Hal tersebut sesuai dengan klasifikasi WHO dimana pada well differentiated terdapat profliferasi sel-sel tumor dimana sel-sel keratin basaloid masih nerdiferensiasi dengan baik membentuk keratin pearl. ${ }^{10}$ Produksi keratin oleh sel-sel adalah simbol dari diferensiasi fungsional yang terjadi. Oleh karena itu kerattin diketahui sebagai salah satu tanda diferensiasi epitel tdak hanya pada identifikasi tumor tetapi juga pada biologi sel, embriologi, dan patologi. ${ }^{1}$

Selain prosentase sel atipik dilakukan perhitungan terhadap sel yang mengalami mitosis. Dari perhitungn sel mitosis didapatkan hasil tertinggi yaitu pada sampel kedua sebanyak 9 sel. Angka tersebut menunjukkan terjadinya peningkatan aktivitas mitosis. Mitosis merupakan proses dimana sel induk membelah menjadi dua anak sel. Fase-fase pada tahap mitosis meliputi profase, metafase, anafase, dan telofase, beberapa dapat terlihat pada potongan jaringan. Sel-sel yang mengalami mitosis disebut juga atipik apabila sel tersebut menunjukkan distribusi kromosom yang abnormal atau benang-benang mitosis dengan jumlah yang berlebihan dan dengan bentukan morfologis yang multipolar. ${ }^{12}$

Inti sel pada sampel OSCC tampak membesar dengan rasio inti dibanding sitoplasma mencapai 1:1.Sedangkan pada keadaan normal perbandingan inti dan sitoplasma sebesar $1: 4$ atau 1:6. Hal tersebut sesuai dengan pendapat Stefanoski et al yaitu pada proses atipik intermediate tampak rasio inti/stoplasma yang tinggi dengan membran inti yang tidak teratur dan hiperkromasi. ${ }^{13}$

Kriteria lain yang digunakan untuk mendiagnosis suatu kanker selain ditemukannya sel atipik, aktivitas mitosis yang meningkat, perubahan perbandingan inti sel dan sitoplasma neoplasma poorly differentiated (high grade) tumor. ${ }^{6}$ Pada gambaran HPA tidak ditemukan ada

adalah terbentuknya angiogenesis. Pada keseluruhan sampel OSCC banyak ditemukan adanya angiogenesis, seperti tampak pada gambaran histopatologi sampel kedua dan kelima. Angiogenesis adalah proses pembentukan pembuluh darah baru yang terjadi secara normal dan sangat penting dalam proses pertumbuhan dan perkembangan. Angiogenesis juga memberikan kontribusi pada karsinogenesis atau pertumbuhan sel kanker yang tidak terkendali dan bersifat ganas, berkembang menjadi suatu yang bersifat patologi seperti pada keadaan inflamasi dan akibat beberapa penyakit infeksi. Pertumbuhan tumor akan difasilitasi oleh proses angiogenesis dengan memberikan oksigenasi pada tumor melalui beberapa proses bertahap, meliputi proliferasi sel endotel, motilitas sel endothelial melalui matriks ekstraseluler, dan diferensiasi kapiler. Proses angiogenesis sebagai indikator adanya perubahan status sel kanker dari jinak menjadi ganas. ${ }^{14}$

Dengan demikian dapat disimpulkan bahwa pada penelitian ini yang ditemukan adalah well differentiated sebanyak 3 sampel diikuti oleh moderately differentiated sebanyak 2 sampel, dan poorly differentiated sebanyak 1 sampel.

\section{DAFTAR PUSTAKA}

1. Hanna, Paul. 2008. Disorders of cell growth \& neoplasia. General pathology I (VPM 152).

2. Syafriadi, M. 2008. Patologi Mulut, Tumor Neoplastik dan Non Neoplastik. Yogyakarta: Andi.

3. Robbins S. \& Kumar V. 2005. Buku Ajar Patologi 1. Jakarta : EGC.

4. Koch FP, Kunkel M, Biesterfeld S, Wagner W. 2011. Diagnostic efficiency of differentiating small cancerous and precancerous lesions using mucosal brush smears of the oral cavity: A prospective and blinded study. Clin Oral Investig., vol. 15 pp. 763-9.

5. Messadi DV. 2013. Diagnostic aids for detection of oral precancerous conditions. Int $J$ Oral Sci. Vol 5. Pp. 59-65

6. Grossman D \& Leffel DJ. 2008. Squamous Cell Carcinoma. In: Wolff K, Goldsmith LA, Katz SI, Gilchrest BA, Leffell ASPJ, editors. Fitzpatrick`s Dermatology in General 
Jurnal Biosains Pascasarjana Vol. 17 (2015) pp

(C) (2015) Sekolah Pascasarjana Universitas Airlangga, Indonesia

Medicine. 7 ed. New York: McGraw-Hill;. Pp. 1028-36

7. Poh CS, Beream K, Williams P, Rosin M. and Zhang, L. 2008. Biopsy and Histopathologic Diagnosis Of Oral Premalignant and Malignant Lesion. Journal of the Canadian Dental Association, vol.74, no. 3, pp. 283-288

8. Neena DP, Siddarth SA, Keyuri PB, Munira JF. 2011. Histological Grading of oral cancer : comparison of different systems and their relation to lymph nodes metastasis. Departement of Pathology, Shree Krishna Hospital and Pramukh Swami Medical College, Karamsad Gujarat India. Vol 2 pp. 136-142

9. Koshy M, Mahmod U, Goloubeva O, Suntharalingan M. 2011. Adjuvant Radiation Therapy for High-Grade and/or Locally Advanced Major Salivary Gland Tumors. American Medical Association

10.Sudiono J, Kurniadhi B, Hendrawan A, Djimantoro B. 2003. Ilmu Patologi. Jakarta, EGC. pp. 144-47

11. Smitha T, Mohan CV, Hemavathy S. 2017. Clinicopathological features of oral squamous cell carcinoma: A hospital-based retrospective study. J NTR Univ Health Sci. Vol.6. Pp. 2934

12.Lau CK., Delmar VA., Chan RC., Phung Q Bernis C, Fichtman,B, et al. 2009. Transportin regulates major mitotic assembly events: from spindle to nuclear pore assembly. Mol. Biol. Cell Vol. 20 Pp. 4043-4058.

13.Stefanovski PD, Bidoli E, De Paoli A, Buonadonna A, Boz G, Libra $M$, et al. 2002. Prognostic factors in soft tissue sarcomas: a study of 395 patients. Eur J Surg OncolMar No..28 Vol.2. Pp.153-64

14.Bergers G \& Hanahan D. 2008. Modes of resistance to anti-angiogenic therapy. Nat Rev Cancer Vol.8 Pp. 592-603. 